\title{
EFFECT OF SEX AND L-CARNITINE ADDITION ON GROWTH PERFORMANCE AND CARCASS QUALITY OF SUDANI DUCKLINGS
}

\author{
A. L. Awad; H. N. Fahim; M. M. Beshara; and A.M. El-Shhat
}

Anim. Prod. Res. Inst., Agric. Res. Center, Minis. of Agric. Dokki, Giza.

Corresponding author: Awad L. Awad; E-mail: awad1512@yahoo.com

Received: 22/08/2017

Accepted: 13/09/2017

\begin{abstract}
Two hundred and eighty eight of Sudani ducklings (144 from both males and females), 4-wks-old were used, weighed and divided into six experimental groups (three replicates each) for both sexes to investigate the effect of ducklings sex and dietary L-carnitine (LC) addition $(0,150,300,450,600$ and $750 \mathrm{mg} / \mathrm{kg}$ diet $)$ in a factorial design $(2 \times 6)$ on growth performance, carcass traits and quality and blood constituents as well as economic efficiency under Egyptian summer conditions. Results indicated that, live body weight (LBW), body weight gain (BWG), feed consumption (FC) and production index (PI) were significantly $(\mathrm{P} \leq 0.01)$ higher for male ducklings than female, also, feed conversion ratio (FCR) was significantly $(\mathrm{P} \leq 0.05)$ improved during the whole experimental period (4-16 wks of age). However, dietary LC addition resulted in a significant $(\mathrm{P} \leq 0.01)$ improvement in BWG, FCR and PI during the experimental period than the control group. Abdominal fat and breast and thigh yield $(\%)$ were significantly higher for female than male ducklings. Eviscerated carcass and total edible parts $(\%)$ were significantly $(\mathrm{P} \leq 0.01)$ improved by supplementing different LC levels to the diet, while abdominal fat was significantly $(\mathrm{P} \leq 0.01)$ decreased. Breast yield $(\%)$ was significantly $(\mathrm{P} \leq 0.05)$ higher by feeding $450 \mathrm{mg} \mathrm{LC} / \mathrm{kg}$ diet, only than the control, however, thigh yield $(\%)$ was significantly $(\mathrm{P} \leq 0.01)$ improved by feeding different LC levels except of $300 \mathrm{mg} / \mathrm{kg}$. Furthermore, muscles ether extract (EE) content was significantly higher in both breast and thigh of female's ducklings than males, while crude protein (CP) was significantly decreased for female thigh muscles. Addition different LC levels to the diet resulted in a significant improvement of $\mathrm{CP}$ content for both breast and thigh muscles, while EE content was significantly decreased for them. Serum total cholesterol was significantly increased for female than male ducklings, whereas, both serum triglycerides and total cholesterol constituents were significantly decreased by supplementing different LC levels to the diet than the control. Supplementing different LC levels to the diet resulted in a significant increase in lymphocytes (L) cells (\%), while heterophils $(\mathrm{H})$ cells $(\%)$ and $\mathrm{H} / \mathrm{L}$ ratio were significantly $(\mathrm{P} \leq 0.01)$ decreased than the control group. Net return and economic efficiency were significantly lowered for female ducklings than male, however, they significantly improved for ducklings fed different LC diets than those fed the control diet. These results indicated that dietary L-carnitine additionwith 150 or $300 \mathrm{mg} / \mathrm{kg}$ could be maximize and improve the growth performance and carcass traits and quality as well as economic efficiency of Sudani ducklings especially males during growth period (4-16 wks of age) under Egyptian summer conditions.
\end{abstract}

Key words: ducklings sex, L-carnitine, growth performance, carcass and meat quality. 


\section{INTRODUCTION}

The world food consumption pattern has changed over the last decades, with consumers becoming more and more aware of food quality attributes. Nowadays, quality attributes include not only nutritional and sensory aspects, but also food safety and environmental and animal wellbeing during rearing (Castillo et al., 2007). Although, the demand on animal protein is superfast worldwide, however the supply is not as sufficient to cover the demand. Moreover, environmental conditions had direct effect on poultry production. Heat stress interferes and suppresses productive efficiency by reducing growth performance and immune response (Lara and Rostagno, 2013). Physiological additives are those that help the normal development of physiological functions or that make up for their deficiencies. LCarnitine supplementation as physiological feed additives, L-carnitine a zwitterionic compound synthesized in vivo from lysine and methionine, it is essential for the transport of long chain fatty acid across the inner mitochondria membrane for $\beta$-oxidation and remove toxic accumulations of fatty acids from mitochondria (Michalczuk et al., 2012). Consequently, L-carnitine supplementation in diets reduces the amount of longchain fatty acids availability for esterification to triacylglycerols and storage in the adipose tissue, also, Lcarnitine has antioxidant properties (Xu et al., 2003).

Water fowl is one of the poultry species which could be used in solving the lake of animal protein in human nutrition. Ducks is a major producer of high quality animal protein, because it's high nutritive value as a result of their contents from essential amino acids. The limiting factors for duck meat consumption is excessive fatness, and ducks carcass had relatively high price as well as lack of tradition for consumption of this type of meat. Some studies was conducted to find ways of improving productivity by increasing feed efficiency and lowering feed cost for ducks (Bernacki et al., 2008). In Egypt, Sudani ducks is a native breed, which like Muscovy ducks breed, however, their growth performance is inferior to meattype duck breeds because growth traits are subject to significant confounding factors including genetics, sex and environmental variables (Awad et al., 2014). Therefore, the objective of this study was aimed to investigate the potential effect of dietary L-carnitine supplementation on growth performance, some physiological parameters, carcass traits and quality as well as economic efficiency of both sexes of local Sudani ducklings under Egyptian summer conditions.

\section{MATERIALS AND METHODS}

\section{Birds and management:}

This study was carried out at El - Serw Water Fowl Research Station, Animal Production Research Institute, Agricultural Research Center, Ministry of Agriculture, Egypt. It was carried out during May to July months (summer conditions). Two hundred and eighty eight Sudani ducklings (144 of both males and females), 4-wks-old were used, weighed and distributed into six experimental groups for both sexes. According to the treatment groups, the ducklings were arranged in a factorial (2 $\times 6$ ) design (sex and L-carnitine levels). Each treatment group for each sex was consisted of three replicates of 8 ducklings each. Ducklings were reared under similar hygienic, environmental and managerial conditions. Feed and 
Ducklings sex, L-carnitine, growth performance, carcass and meat quality.

fresh water were available all the time through the experimental period. Ducklings were fed a starter diet from 4 up to 8 wks and a grower diet from $8-16$ wks of age. Basal experimental diets were prepared and divided into six parts then supplemented with graded levels of Lcarnitine $(0,150,300,450,600$ and 750 $\mathrm{mg} / \mathrm{kg} \mathrm{diet}$ ) and provided to ducklings from 4-wk until 16 wks of age. The composition and calculated analysis of the basal diets are shown in Table 1.

\section{Data collection and estimated parameters:}

1. Growth performance parameters: Body weight of ducklings was recorded at 4 and 16 wks of age. Feed consumption was recorded for each replicate per treatment during the whole experimental period. Body weight gain and feed conversion ratio were calculated through the experimental period (4-16wks of age), also, production index (PI) was calculated for the same period as live weight $(\mathrm{Kg}) /$ feed conversion $\mathrm{x} 100$ according to North (1981).

\section{Blood hematological parameters: At} the $12^{\text {th }}$ week, blood samples were collected in vial tubes containing EDTA as anticoagulant from three ducklings of both male and female per each treatment to determine hematological traits such as Heterophils (H) and lymphocytes (L) were counted in different microscopic fields in a total of 200 WBCS by the same person, and the $\mathrm{H}$ : $\mathrm{L}$ ratios were calculated (Gross and Siegel, 1986).

\section{Blood serum biochemical analysis:} At the end of the $16^{\text {th }}$ week of age, blood samples were collected in centrifugation tubes from three ducklings for both males and females per each treatment without anticoagulant and kept at room temperature for one hour to clot. The samples were centrifuged at $3500 \mathrm{rpm}$ for 15 minutes to separate clear serum. After that, serum total protein, triglycerides, total cholesterol and liver enzymes activities (aspartate "AST, U/L:" and alanine amino transaminases "ALT, U/L) were calorimetrically determined using available commercial Kits.

4. Slaughter traits: At the end of $16^{\text {th }}$ week of age, three ducklings from each sex (male or female) per each treatment group were randomly taken, fasted for 12 hours before slaughtering and individually weighed pre-slaughtering and post complete bleeding. Then, scalding, feather picking and evisceration were performed and different body parts, organs and abdominal fat were dissected and weighed. Relative weights of carcass traits were expressed to live weight. Breast and thigh parts were cut (with skin) from the carcass and weighed, then their relative yields were expressed to eviscerated carcass weight. Samples of breast and thigh muscles were taken , chopped and dried, then chemically analyzed for crude protein (CP), ether extract (EE), and ash according to AOAC (1995) and the values were expressed on DM basis.

5. Economic efficiency and net return were calculated based on the prices of Lcarnitine $(95.0 \%)$ hydrochloride (250 LE/ one $\mathrm{kg}$ ), one $\mathrm{kg}$ of live body weight (30.0 LE) and one duckling male and female price at 4 wks of age was 18 and 15 LE, respectively which prevailing during the experimental time.

6. Statistical analysis: Data obtained were statistically analyzed using the General linear model of SAS (2004). In this study, the model used was $2 \times 6$ factorial design. Considering the ducklings sex (S) and L-carnitine levels 
(LC) as the main effects, the model used was: $Y_{\mathbf{i j f k}}=\mu+\mathrm{T}_{\mathbf{i}}+\mathrm{R}_{\mathbf{j}}+(\mathrm{TR})_{\mathbf{i j}}+$ eij where: $\mathrm{Y}_{\mathrm{ijfk}}=$ an observation; $\mu=$ Overall mean; $\mathrm{T}=$ Effect of sex $; \mathrm{i}=(1$ and 2$) ; \mathrm{R}=$ Effect of LC level ; $\mathrm{j}=(1,2, .$. and 6$)$; $\mathrm{TR}=$ Effect of interaction between $\mathrm{S}$ and LC level ; eij = Experimental random error. Differences among treatment means were estimated by Duncan's multiple range test (Duncan, 1955).

\section{RESULTS AND DISCUSSION}

\section{Growth performance:-}

Duckling's sex had significant effect on live body weights (LBW) and body weight gain (BWG) of Sudani ducklings (Table 2). Live body weight of female ducklings was significantly lighter by $39.95 \%$ than male ducklings at 16 wks of age, so that, BWG was significantly lower by $43.73 \%$ during the experimental period (4-16 wks of age). These results may be due to male ducklings have a greater growth rate than females and it tend to mature earlier as well as it consumed more amount of feed and better feed conversion ratio. The mentioned results are in agreement with those obtained by Wawro et al.(2004) who reported that mean body weight of Muscovy females $(2.879 \mathrm{~g})$ was significantly $(\mathrm{P} \leq 0.01)$ lower than males $(4.573 \mathrm{~g})$ at $12 \mathrm{wks}$ of age. Also, Awad et al. (2014) found that LBW and BWG were significantly lower for female than male Sudani ducklings at different ages during growth period. On the other hand, dietary L-carnitine (LC) addition had significant effect on LBW and BWG (Table 2). Ducklings LBW was significantly improved by $14.43,12.17$, $9.40,13.10$ and $11.33 \%$ for ducklings fed diet supplemented with 150, 300, 450,600 and $750 \mathrm{mg} \mathrm{LC} / \mathrm{kg}$, respectively as compared with those fed the control diet (un-supplemented) at 16 wks of age, whereas, BWG was significantly improved by 19.48, 16.36, 13.31, 17.56 and $15.79 \%$ for the same groups compared to control one during the experimental period (4-16 wks of age).These improvements may be due to LC play a major role by increasing plasma insulin-like growth factor-I concentration, which serves as stimulating substances for chick's growth (Xu et al., 2003). Also, it may be due to improve the utilization of dietary ingredients as a result of LC transfer the long-chain fatty acids across the inner mitochondrial membrane and controls the rates of $\beta$-oxidation of long-chain fatty acids as well as it plays a pivotal role in energy metabolism (Arslan, 2003).These results are in agreement with those of Parsaeimehr et al. (2014)who reported that dietary L-carnitine supplementation (300 mg/kg) had significantly improved body weight and body weight gain of broiler chickens. Taklimi et al. (2015) found that bird's BWG had significant $(\mathrm{P}<0.05) \quad$ increase during the experimental period $(0-42 \mathrm{~d}$ of age) by supplementing 600 up to $800 \mathrm{mg} \mathrm{LC} / \mathrm{kg}$ diet as compared to the control group. Also, Awad et al. (2016) reported that LBW and BWG for Domyati ducklings were significantly improved by LC supplementation (300-450 mg/kg diet). However, Deng et al. (2006) found that feeding diets supplemented with 100 or $1000 \mathrm{mg} \mathrm{LC} / \mathrm{kg}$ of egg Leghorn type chickens for short-term (4 wks) after hatching induced no difference in growth performance. The interaction between duckling's sex and LC addition had significant effect on LBW and BWG (Table 2). All females ducklings fed LC diets had significantly $(\mathrm{P} \leq 0.01)$ lower LBW and BWG than male's ducklings fed the same diet at 16 wks of age. 
Ducklings sex, L-carnitine, growth performance, carcass and meat quality.

Generally, male ducklings fed 150 or 600 $\mathrm{mg} \mathrm{LC} / \mathrm{kg}$ diet had the heaviest LBW and the best $\mathrm{BWG}$, while, females ducklings fed the control diet $(0.0 \mathrm{mg} \mathrm{LC} / \mathrm{kg})$ had the lowest LBW and BWG values than other interactions. This may be due to the effect of the sex of the ducklings, which affects the quantity of the diet consumed and hence the live body weight and the increase in it.

\section{Feed consumption:-}

Feed consumption (FC) was significantly lower for female than male duckling during the experimental period (Table 2). It was significantly $(\mathrm{P} \leq 0.01)$ decreased by $36.25 \%$ during the period of $4-16$ wks of age. These results may be due to female duckling have a poor growth rate which need low feed consumption to keep pace with decreasing body weights compared to male ducklings. These results are in agreement with those obtained by Awad et al. (2014) who reported that Sudan female ducklings had significantly less feed consumption $(9.43 \mathrm{~kg})$ than male $(14.15 \mathrm{~kg})$ during the growing period (20 wks).On the other hand, no significant differences were observed in FC of Sudani ducklings due to dietary LC addition during the experimental period (Table 2). The interaction between duckling's sex and dietary LC addition had no significant effect in FC during the experimental period. The lowest $\mathrm{FC}$ value was recorded for female ducklings fed varying LC levels comparing to male ducklings fed the same diets during the experimental period. This may be due to ducklings are able to compensate their feed intake according to their energy requirements as well as the experimental diet had similar metabolizable energy. This result is similar with Murali et al. (2015) who reported that dietary LC addition $(900 \mathrm{mg} / \mathrm{kg}$ diet $)$ did not affect feed consumption in broilers during growing period (0-6 wks). Also, Awad et al. (2016) reported that FC for Domyati ducklings was not significantly affected due to LC supplementation with 150up to $600 \mathrm{mg} / \mathrm{kg}$ diet. However, Bayram et al. (1999) detected that significant decreases in FC in quails fed diet supplemented with $500 \mathrm{mg} \mathrm{LC} / \mathrm{kg}$.

\section{Feed conversion ratio:-}

Feed conversion ratio (FCR) significantly $(\mathrm{P} \leq 0.05)$ affected due to duckling's sex during the experimental period (Table 2). It was significantly depressed by $13.51 \%$ for female than male ducklings. These results may be due to Sudani female ducklings had lighter body weight gain than male during growth period. These results are in agreement with those obtained by Awad et al, (2014) who reported that Sudani female ducklings had significantly attenuated feed conversion ratio than male ducklings during the growing period (20 wks of age).Also, FCR had significantly $(\mathrm{P} \leq 0.01)$ affected due to dietary LC addition (Table 2). It was significantly improved by $15.65,15.45,13.01,15.85$ and $10.37 \%$ for ducklings fed diet supplemented with $150,300,450,600$ and $750 \mathrm{mg} \mathrm{LC} / \mathrm{kg}$, respectively than those fed the control diet. Interaction between duckling's sex and dietary LC addition had no significant effects on FCR during the experimental period. The best FCR values were occurred for male ducklings fed different LC diets, however, the lowest values recorded for female ducklings fed the control diet during the overall experimental period (Table 2). Generally, the improvement in FCR is associated with decreasing FC and increasing LBW value which may be attributed to improve BWG of ducklings. The improvement in FCR in this study 


\section{A. L. Awad et al.}

may be due to L-carnitine enhances fatty acid burning, thus decreasing calorie requirements, as well as, it improves intestinal mucous membrane by active and passive mechanisms (Fathi and Farahzadi, 2014). These results are similar with those obtained by AbdelFattah et al. (2014) who reported that a significant improvement in FCR of quails was occurred as a result of dietary supplementing $200-400 \mathrm{mg} \mathrm{LC} / \mathrm{kg}$ than the control. Also, Awad et al. (2016) reported that FCR for Domyati ducklings were significantly improved by dietary LC supplementation with 300 up to 450 $\mathrm{mg} / \mathrm{kg}$. On the other hand, Deng et al. (2006) found that L-carnitine (100 or $1000 \mathrm{mg} / \mathrm{kg}$ ) supplementation had no significant effect on feed utilization efficiency for egg Leghorn type chickens during four weeks after hatching.

\section{Production Index (PI):-}

Significant $(\mathrm{P} \leq 0.01) \quad$ differences were observed in production index (PI) among the experimental treatments due to duckling's sex and L-carnitine (LC) addition (Table 2). Female ducklings had significantly lower PI by $46.90 \%$ than male ducklings during the experimental period (4-16 wks of age). These results are similar with those obtained by Awad et al. (2014) who reported that Sudan female ducklings had significantly lower PI than male ducklings during growing period (20 wks). These results may be due to female ducklings had lower BWG and higher FCR values than male ducklings. Moreover, ducklings PI was significantly improved by $34.53,30.85,24.14,33.47$ and $25.17 \%$ for ducklings fed diet supplemented with 150, 300, 450, 600 and $750 \mathrm{mg} \mathrm{LC} / \mathrm{kg}$, respectively as compared with those fed the control diet during the experimental period (4-16wks of age). The interaction between duckling's sex and dietary supplementing LC had significant $(\mathrm{P} \leq 0.05)$ effect on ducklings PI , the best value was recorded for male ducklings fed 150 or $600 \mathrm{mg}$ $\mathrm{LC} / \mathrm{kg}$ diet, whereas, the lowest value was occurred for female ducklings fed the control diet. These results may be due to L-carntine improves BWG and FCR as well as not increases feed consumption during the overall period. Also, it may due to L-carnitine has the ability to improve the use of dietary nitrogen, whether directly through sparing its precursors (methionine and lysine) for protein biosynthesis and other cellular functions or indirectly by optimizing the balance between essential and nonessential amino acids within the cell (Sarica et al. , 2005), which subsequently improved growth performance. These results are similar with those obtained by Awad et al. (2016) who reported that PI for Domyati ducklings was significantly improved by dietary LC supplementation with 300 up to $450 \mathrm{mg} / \mathrm{kg}$.

\section{Carcass traits:-}

Sudani female ducklings had significantly lighter slaughter weight than male ducklings by $37.91 \%$ at 16 wks of age (Table 3). Both eviscerated carcass and total edible parts $(\%)$ were numerically similar for both female and male ducklings, while abdominal fat (\%) was significantly higher by 20.41 for female than male ducklings, respectively. Moreover, breast and thigh yield (expressed as percentage of eviscerated carcass weight) were significantly higher by 6.02 and $4.02 \%$ for female ducklings than males, respectively. These results are in agreement with those obtained by Sari et al. (2013) who reported that Muscovy female ducklings had lighter slaughter weight, eviscerated carcass and total edible part weights than male ducklings at 
Ducklings sex, L-carnitine, growth performance, carcass and meat quality.

12 wks of age. Also, Awad et al. (2014) reported that slaughter weight of female Sudani ducklings was significantly lighter than male, while total giblets and abdominal fat were significantly increased. However, they found that eviscerated carcass and total edible part percentages were significantly decreased for female than male ducklings 20 wks of age. On the other hand, all studied carcass traits were significantly affected among the experimental groups due to dietary LC addition (Table 3). Both eviscerated carcass and total edible parts (\%) were significantly improved, while abdominal fat $(\%)$ was significantly decreased by supplementing different LC levels to the diets. The significant improvement of eviscerated carcass and total edible parts (\%) were reached 4.46-6.19 and 4.58$5.85 \%$, respectively, while, abdominal fat $(\%)$ was significantly decreased by $43.01-58.60 \%$ as a result of LC addition comparing to the control. Further, breast yield $(\%)$ was significantly improved by $4.25 \%$ for ducklings fed diet supplemented with $450 \mathrm{LC} / \mathrm{kg}$, but thigh yield (\%) was significantly improved by supplementing different LC levels except of $300 \mathrm{mg} \mathrm{LC} / \mathrm{kg}$ diet than those fed the control diet. The interactions between duckling's sex and level of dietary LC addition had no significant effects on all studied carcass traits except of total giblets (\%). Male ducklings fed LC inclusion level with 300,450 or750 and female duckling fed $150 \mathrm{mg} \mathrm{LC} / \mathrm{kg}$ were recorded the best total edible parts percentage (above 78\%) than other interactions. However, abdominal fat (\%) was decreased by supplementing different LC levels for both male and female ducklings than those fed the control diet. Generally, the improvement of eviscerated carcass and total edible parts percentage may be due to improving the final live weight and decreasing un-edible parts as a result of LC addition to the diet. The decrease of abdominal fat (\%) may be due to L-carnitine prevents fatty tissue buildup, decreases the calorie requirement and increases the tolerance to effort because it may plays a major role to facilitate the removal of short and medium-chain fatty acids from the mitochondria that accumulate as a result of normal and abnormal metabolism and promotes the $\beta$-oxidation of these fatty acids in order to generate adenosine triphosphate (ATP) energy and improve energy utilization by reduce the amount of long-chain fatty acids availability for esterification to triacylglycerols and storage in the adipose tissue ( $\mathrm{Xu}$ et al. 2003).The current findings are in agreement with those obtained by AbdelFattah et al. (2014)who showed that supplemental L-carnitine $(400 \mathrm{mg} / \mathrm{kg}$ diet) significantly increased the dressing percent and decreased abdominal fat $(\%)$ of quails. Awad et al. (2016) reported that total edible parts (\%) for Domyati ducklings was significantly improved, while abdominal fat (\%) was significantly decreased by dietary LC supplementation with 300 up to $450 \mathrm{mg} / \mathrm{kg}$. However, Daskiran and Teeter (2001) observed no significant effect in dressing percentage of broilers in response to dietary Lcarnitine.

\section{Chemical analysis of breast and thigh muscles:-}

Result of Table 4 shows the effect of duckling's sex and dietary L-carnitine (LC) addition and their interactions on chemical analysis of breast and thigh muscles for Sudani ducklings at 16 wks of age. Ether extract (EE) content for both breast and thigh muscles was significantly $(\mathrm{P} \leq 0.05)$ higher for female 


\section{A. L. Awad et al.}

than male duckling, however, thigh muscles crude protein $(\mathrm{CP})$ content was significantly $(\mathrm{P} \leq 0.05)$ decreased. These results are in agreement with Awad et al. (2014) who reported that meat of Sudani female ducklings has significantly higher content of ether extract than male ducklings. Moreover, dry matter and ash content of both breast and thigh muscles were not significantly affected due to duckling's sex. The increase of $\mathrm{EE}$ in female muscles may be due to female birds tend to increase plasma total lipids concentration which resulted in abdominal fat formation prior to egg laying, which could be attributed to an estrogen increases (Simaraks et al., 2004). On the other hand, dietary LC addition had significant effects on all muscles contents for both breast and thigh except of ash content (Table 4). Dry mater content (DM) of breast muscles was significantly higher by 5.21, 7.58 and $4.81 \%$ for ducklings fed diet supplemented with 450, 600 and $750 \mathrm{mg}$ $\mathrm{LC} / \mathrm{kg}$, respectively than those fed the control diet, however, DM content for thigh muscles was significantly increased by feeding $300 \mathrm{mg} \mathrm{LC} / \mathrm{kg}$ diet only. Crude protein content for both breast and thigh muscles was significantly increased, while $\mathrm{EE}$ was significantly $(\mathrm{P} \leq 0.01)$ decreased by supplementing different LC levels to the diet comparing to the control group. The interaction between duckling's sex and LC addition had significant effect on DM content for both breast and thigh muscles as well as CP and EE content for breast muscles only. Generally, DM and $\mathrm{CP}$ content recorded the higher values by feeding LC diets for both male and female ducklings. The highest values of EE content in both breast and thigh were observed with the male and female ducklings fed the control diet, while, the lowest values were occurred by feeding 450 and $600 \mathrm{mg} \mathrm{LC} / \mathrm{kg}$ diet. The decrease of $\mathrm{EE}$ content in breast and thigh muscles by supplementing LC to the diet may be due to LC may acts to decrease the total activities of glucose-6phosphate dehydrogenize, malic dehydrogenize, isocitrate dehydrogenize and lipoprotein lipase and total activities of carnitine palmitoyltransferase-I in breast muscles (Xu et al., 2003), or it may accelerate lipid flux into oxidative metabolism, and consequently reduce the body lipid accumulation (Shuenn et al., 2012). These results are contrary with those obtained by Sarica, et al., (2005) who reported that the supplementation of LC to the broiler diet did not significantly effect on DM, $\mathrm{CP}$ and EE contents of breast or thigh meat at 35-d old Japanese quail. Also, Younis (2015) reported that chemical composition of breast muscle didn't influence by addition of LC supplementation $(500 \mathrm{mg} / \mathrm{kg})$.

\section{Blood serum constituents:-}

Duckling's sex had no significant effects on all studied serum constituents except of total cholesterol at 16 wks of age (Table 5). Serum total cholesterol was significantly higher by $3.31 \%$, while serum triglycerides and liver enzymes activities (AST and ALT) were insignificantly decreased for female than male ducklings. These results may be due to female birds tend to increase plasma total lipids concentration which resulted in abdominal fat formation prior to egg laying, which could be attributed to an estrogen increases (Simaraks et al., 2004).Moreover, dietary LC addition had significant effects on serum triglycerides and total cholesterol (Table 5). Serum triglycerides was significantly $(\mathrm{P} \leq 0.01)$ decreased by 19.91, 16.78, 19.59, 18.59 and $14.44 \%$ for ducklings fed diet 
Ducklings sex, L-carnitine, growth performance, carcass and meat quality.

supplemented with 150, 300, 450, 600 and $750 \mathrm{mg} \mathrm{LC} / \mathrm{kg}$, respectively than those fed the control diet, while, serum total cholesterol constituent was significantly lowered by $10.87-12.33 \%$ for ducklings fed different LC diets. The interaction between duckling's sex and dietary supplementing LC had no significant effect on all studied serum constituents except for triglycerides. The lowest value of serum triglycerides and total cholesterol was occurred for male ducklings fed diet supplemented with 150 $\mathrm{mg} \mathrm{LC} / \mathrm{kg}$, whereas, the highest value was occurred for both male and female ducklings which fed the control diet. Decreasing triglycerides and total cholesterol levels in blood serum for ducklings fed diets supplemented with LC probably related to increasing oxidation of fatty acids by increasing the transportation capacity of fatty acids to inner mitochondrial membrane (Shuenn et al., 2012). Also, LC addition may be increased the activity of lipase and decrease activity of lipoprotein lipase, thereby leading to a higher concentration of fatty acid in serum by accelerating hydrolysis of triglycerides to glycerol and fatty acid (Zhang et al., 2010).The reduction of serum total cholesterol by LC treatment was attained mostly via a decrease of cholesteryl esters rather than by a decrease in free cholesterol. Moreover, it may be due to an increase in biliary sterol excretion or an increase in the conversion of cholesterol to bile acids (Maritza et al., 2006). These results are in agreement with those obtained by Rezaei et al. (2007) who found that adding $\mathrm{LC}(500 \mathrm{mg} / \mathrm{kg}$ ) to diets significantly decreased the level of serum triglyceride and total cholesterol. Xu et al. (2003) reported that adding $\mathrm{LC}$ to diet significantly decreased the level of serum triglyceride in broilers. Hossininezhad et al. (2011) found that supplementing LC with $200 \mathrm{mg} / \mathrm{kg}$ significantly reduced blood cholesterol and triglyceride of Japanese quail. Also, Tufan et al. (2015) found that supplementing LC $(150 \mathrm{mg} / \mathrm{kg}$ diet) to Japanese quails had no significant effect on serum total protein, however, they reported that serum total cholesterol not significantly affected. In contrary to these finding, Arslan (2003) observed that oral LC supplementation at $200 \mathrm{mg} /$ liter water not affect serum cholesterol, total lipids of ducks.

Blood hematological parameters:-

Female ducklings had insignificantly lower ratio of heterophils (H)to lymphocytes (L) cells as compared to male ducklings (Table 5).These results are in agreement with Olayemi et al. (2002) who found that $\mathrm{H} / \mathrm{L}$ ratio was not significantly affected due to varying sex in ducks. These results may be due to female generally exhibit higher immune response than male, especially under pathogenic conditions (Schuurs and Verheul, 1990). Furthermore, dietary LC addition had significant effects on heterophils $(\mathrm{H})$, lymphocytes (L) cells (\%) and $\mathrm{H} / \mathrm{L}$ ratio (Table 5). Lymphocytes cells (\%) was significantly increased, however, heterophils cells (\%) and $\mathrm{H} / \mathrm{L}$ ratio were significantly decreased by supplementing different LC levels in the diet than the control.The interaction between duckling's sex and dietary supplementing LC had no significant effect on studied blood hematological parameters. Heterophils cells $(\%)$ recorded the lowest value while lymphocytes cells (\%) recorded the highest lowest value for male ducklingsfed750 mg LC/kg diet. These results may be due to $\mathrm{L}$-carnitine had strengthened immune function by 


\section{A. L. Awad et al.}

enhancing antibody responses (Deng et al., 2006). Also, it may plays a major role in stabilizing cell membranes and in regulating the function of ion channels (role in calcium transport) by reducing the amount of oxidative damage that occurs as a result of peroxidation of polyunsaturated fatty acids found in membrane phospholipids (Kalaiselvi and Panneerselvam, 1998). These results are in agreement with those obtained by Jameel (2014) who reported that RBCs count and hemoglobin content were increased, while $\mathrm{H} / \mathrm{L}$ ratio was significantly better for chicks fed diet supplemented with $50 \mathrm{mg} \mathrm{LC/} \mathrm{Kg}$ as compared with chicks which fed the control diet.

\section{Economic efficiency:-}

Calculations of economic efficiency (EEF) were listed in Table 6. Duckling's sex had significant effect on all economic efficiency parameters during the experimental period (4-16 wks of age) of Sudani ducklings. Economic efficiency was significantly lower by $39.53 \%$ for female than male ducklings. These results may be due to female ducklings have a low body weight, total return and net return comparing to male ducklings. On the other hand, varying levels of LC addition had significant effects on both total and net return as well as EEF (Table 6). Total cost was insignificantly increased by supplementing different LC levels to the diet except of $750 \mathrm{mg} / \mathrm{kg}$ level. Total return was significantly increased by $14.42,12.17,9.39,13.09$ and $11.32 \%$ for ducklings fed diet supplemented with 150, 300, 450, 600 and $750 \mathrm{mg} \mathrm{LC} / \mathrm{kg}$, respectively than those fed the control diet. Generally, net return and EEF values were significantly higher by feeding different LC diets than the control, EEF values were significantly improved by $58.39,53.28,36.86,50.36$ and $24.09 \%$ for ducklings fed diet supplemented with $150,300,450,600$ and $750 \mathrm{mg} \mathrm{LC} / \mathrm{kg}$, respectively than those fed the control diet. It's clearly that supplementing 150 or $300 \mathrm{mg} \mathrm{LC} / \mathrm{kg}$ diet resulted in the best feeding EEF during the experimental period (4-16 wks of age) for Sudani ducklings. Respecting to the interaction between duckling's sex and LC levels, there were a significant differences in LC cost and total return only. The highest values of EEF were observed for male ducklings fed 150, 300 and $600 \mathrm{mg} \mathrm{LC} / \mathrm{kg}$ diet, while, the lowest value was occurred for female ducklings fed the control and $750 \mathrm{mg} \mathrm{LC} / \mathrm{kg}$ diets.

\section{CONCLUSION}

Based on the present data, it is concluded that L-carnitine inclusion with 150 or 300 $\mathrm{mg} / \mathrm{kg}$ diet had positive effects on growth performance, carcass traits and quality as well as economic efficiency of Sudani ducklings especially males without any deleterious effects on any studied physiological parameters under Egyptian environmental conditions. 
Ducklings sex, L-carnitine, growth performance, carcass and meat quality.

Table (1): Composition and calculated analysis of the basal diets.

\begin{tabular}{|l|c|c|}
\hline \multicolumn{1}{|c|}{ Ingredients \% } & $\begin{array}{c}\text { Starter } \\
(\mathbf{4 - 8} \text { wks })\end{array}$ & $\begin{array}{c}\text { Grower } \\
(\mathbf{1 2 - 1 6} \text { wks })\end{array}$ \\
\hline Yellow Corn & 63.00 & 72.00 \\
Soybean meal (44 \%) & 33.20 & 17.80 \\
Wheat bran & 0.00 & 6.40 \\
Di-calcium phosphate & 1.60 & 1.60 \\
Limestone & 1.50 & 1.50 \\
Vit. \& Min. premix ${ }^{1}$ & 0.30 & 0.30 \\
NaCl & 0.35 & 0.35 \\
DL. Methionine & 0.05 & 0.05 \\
Total & 100.0 & 100 \\
\hline Calculated Analysis ${ }^{2}$ & \multicolumn{2}{|c|}{} \\
\hline Crude protein, \% & 20.01 & 15.00 \\
ME, ( Kcal / kg ) & 2849 & 2892 \\
Crude fiber, \% & 3.71 & 3.53 \\
Ether extract, \% & 2.66 & 3.07 \\
Calcium, \% & 1.03 & 1.00 \\
Av. Phosphorus, \% & 0.44 & 0.42 \\
Lysine, \% & 1.05 & 0.70 \\
Methionine, \% & 0.37 & 0.30 \\
Methio + Cyst, \% & 0.71 & 0.58 \\
Sodium,\% & 0.16 & 0.16 \\
Price, (LE/kg) ${ }^{3}$ & 4.951 & 4.438 \\
\hline
\end{tabular}

1- Each $3 \mathrm{~kg}$ of the Vit and Min. premix manufactured by Agri-Vit Company, Egypt contains: Vitamin A 10 MIU, Vit. D 2 MIU, Vit E 10 g, Vit. K 2 g, Thiamin 1 g, Riboflavin 5 g, Pyridoxine 1.5 g, Niacin 30 g, Vit. B12 10 mg, Pantothenic acid 10 g, Folic acid $1.5 \mathrm{~g}$, Biotin $50 \mathrm{mg}$, Choline chloride $250 \mathrm{~g}$, Manganese $60 \mathrm{~g}$, Zinc $50 \mathrm{~g}$, Iron $30 \mathrm{~g}$, Copper $10 \mathrm{~g}$, Iodine $1 \mathrm{~g}$, Selenium 0. $10 \mathrm{~g}$, Cobalt $0.10 \mathrm{~g}$. and carrier $\mathrm{CaCO} 3$ to $3000 \mathrm{~g}$..

2- According to Feed Composition Tables for animal and poultry feedstuffs used in Egypt (2001).

3- Price of one $\mathrm{kg}$ (LE) at time of experiment for different ingredients : yellow corn , 3.70 ; Soy bean meal, 6.70; wheat bran, 2.90; Di-calcium Phosphate,15.0 ; limestone, 0.50 ; Vit\&Min.premx,35.0; Nacl,1.0 and Methio.,80.0 . 
Table (2): Effect of sex, dietary L-carnitine addition and their interaction on growth performance of Sudani ducklings during experimental period.

\begin{tabular}{|c|c|c|c|c|c|c|c|}
\hline \multirow{2}{*}{\multicolumn{2}{|c|}{$\begin{array}{l}\text { Main Traits } \\
\text { effects }\end{array}$}} & \multicolumn{2}{|c|}{ LBW (g) } & \multirow{2}{*}{$\begin{array}{c}\text { BWG } \\
(\mathrm{g})\end{array}$} & \multirow{2}{*}{$\begin{array}{c}\text { FC } \\
(\mathrm{kg})\end{array}$} & \multirow{2}{*}{ FCR } & \multirow{2}{*}{$\begin{array}{l}\text { PI } \\
\%\end{array}$} \\
\hline & & 4 wk. & 16 wk. & & & & \\
\hline \multicolumn{8}{|c|}{ Sex effect $(S)$} \\
\hline \multirow{2}{*}{\multicolumn{2}{|c|}{$\begin{array}{c}\text { Male (M.) } \\
\text { Female (F.) }\end{array}$}} & $697.0^{\mathrm{a}}$ & $3463.5^{\mathrm{a}}$ & $2766.3^{\mathrm{a}}$ & $11.208^{\mathrm{a}}$ & $4.07^{b}$ & $85.76^{\mathrm{a}}$ \\
\hline & & $523.0^{\mathrm{b}}$ & $2079.7^{b}$ & $1556.7^{b}$ & $7.145^{\mathrm{b}}$ & $4.62^{\mathrm{a}}$ & $45.54^{b}$ \\
\hline \multicolumn{2}{|c|}{ Pooled SEM } & 7.6 & 18.4 & 21.3 & 0.081 & 0.05 & 1.16 \\
\hline \multicolumn{2}{|c|}{ Significance } & $* *$ & $* *$ & $* *$ & $* *$ & $*$ & $* *$ \\
\hline \multicolumn{8}{|c|}{ L-carnitine effect (LC, mg/kg diet) } \\
\hline \multicolumn{2}{|c|}{0.0} & 618.0 & $2518.0^{c}$ & $1900.0^{\mathrm{b}}$ & 9.116 & $4.92^{\mathrm{a}}$ & $52.65^{b}$ \\
\hline \multicolumn{2}{|c|}{150} & 611.1 & $2881.3^{\mathrm{a}}$ & $2270.1^{\mathrm{a}}$ & 9.259 & $4.15^{\mathrm{b}}$ & $70.83^{\mathrm{a}}$ \\
\hline \multicolumn{2}{|c|}{300} & 613.2 & $2824.5^{\mathrm{ab}}$ & $2211.3^{\mathrm{a}}$ & 9.094 & $4.16^{\mathrm{b}}$ & $68.89^{\mathrm{a}}$ \\
\hline \multicolumn{2}{|c|}{450} & 601.8 & $2754.6^{\mathrm{b}}$ & $2152.9^{\mathrm{a}}$ & 9.099 & $4.28^{\mathrm{b}}$ & $65.36^{\mathrm{a}}$ \\
\hline \multicolumn{2}{|c|}{600} & 614.3 & $2847.9^{\mathrm{ab}}$ & $2233.7^{\mathrm{a}}$ & 9.079 & $4.14^{\mathrm{b}}$ & $70.27^{\mathrm{a}}$ \\
\hline \multicolumn{2}{|c|}{750} & 603.1 & $2803.2^{\mathrm{ab}}$ & $2200.1^{\mathrm{a}}$ & 9.411 & $4.41^{\mathrm{b}}$ & $65.90^{\mathrm{a}}$ \\
\hline \multicolumn{2}{|c|}{ Pooled SEM } & 13.08 & 31.94 & 37.0 & 0.141 & 0.09 & 2.00 \\
\hline \multicolumn{2}{|c|}{ Significance } & NS & $*$ & $* *$ & $\mathrm{NS}$ & $* *$ & $* *$ \\
\hline \multicolumn{8}{|c|}{ Interaction } \\
\hline \multirow[t]{2}{*}{ Sex } & LC & & & & & & \\
\hline & 0.0 & 698.3 & $3166.7^{b}$ & $2468.3^{b}$ & 11.171 & 4.53 & $70.00^{b}$ \\
\hline \multirow{5}{*}{$\frac{\stackrel{0}{\pi}}{\sum}$} & 150 & 706.1 & $3581.7^{\mathbf{a}}$ & $2875.6^{\mathbf{a}}$ & 11.223 & 3.90 & $91.80^{\mathrm{a}}$ \\
\hline & 300 & 685.8 & $3473.3^{\mathrm{a}}$ & $2787.5^{a}$ & 11.083 & 3.98 & $87.56^{\mathrm{a}}$ \\
\hline & 450 & 691.0 & $3415.1^{\mathrm{a}}$ & $2724.1^{\mathrm{a}}$ & 11.100 & 4.08 & $83.90^{\mathrm{a}}$ \\
\hline & 600 & 705.4 & $3558.3^{a}$ & $2852.9^{a}$ & 11.085 & 3.89 & $91.74^{\mathrm{a}}$ \\
\hline & 750 & 696.7 & $3585.8^{\mathrm{a}}$ & $2889.2^{\mathrm{a}}$ & 11.585 & 4.02 & $89.55^{\mathrm{a}}$ \\
\hline \multirow{6}{*}{ 营 } & 0.0 & 537.6 & $1869.3^{d}$ & $1331.7^{d}$ & 7.061 & 5.32 & $35.31^{\mathrm{d}}$ \\
\hline & 150 & 516.1 & $2180.8^{c}$ & $1664.7^{\mathrm{c}}$ & 7.294 & 4.39 & $49.85^{c}$ \\
\hline & 300 & 540.6 & $2175.7^{\mathrm{c}}$ & $1635.1^{\mathrm{c}}$ & 7.104 & 4.35 & $50.22^{c}$ \\
\hline & 450 & 512.5 & $2094.2^{\text {cd }}$ & $1581.7^{\mathrm{c}}$ & 7.098 & 4.49 & $46.82^{c}$ \\
\hline & 600 & 523.1 & $2137.5^{\mathrm{c}}$ & $1614.4^{c}$ & 7.075 & 4.38 & $48.79^{c}$ \\
\hline & 750 & 509.4 & $2020.6^{\text {cd }}$ & $1511.1^{\mathrm{c}}$ & 7.238 & 4.80 & $\begin{array}{l}42.25^{\mathrm{c}} \\
\mathrm{d}\end{array}$ \\
\hline \multicolumn{2}{|c|}{ Pooled SEM } & 18.50 & 45.2 & 52.3 & 0.199 & 0.13 & 2.83 \\
\hline \multicolumn{2}{|c|}{ Significance } & $\mathrm{NS}$ & $*$ & $*$ & NS & NS & $*$ \\
\hline
\end{tabular}

$\mathrm{LBW}=$ live body weight; $\mathrm{BWG}=$ body weight gain; $\mathrm{FC}=$ feed consumption; $\mathrm{FCR}=$ feed conversion ratio; $\mathrm{PI}=$ production index

a,b,c... d :means in the same column within each item bearing different superscripts are significantly different $(\mathrm{P} \leq 0.05), \mathrm{SEM}=$ stander error mean; $\mathrm{NS}=$ non-significant; $*=$ $\mathrm{P} \leq 0.05 ; * *=\mathrm{P} \leq 0.01$ 
Ducklings sex, L-carnitine, growth performance, carcass and meat quality.

Table (3): Effect of sex, dietary L-carnitine addition and their interaction on carcass traits of Sudani ducklings at 16 wks of age

\begin{tabular}{|c|c|c|c|c|c|c|c|c|}
\hline \multirow{2}{*}{\multicolumn{2}{|c|}{$\begin{array}{l}\text { Main Traits } \\
\text { effects }\end{array}$}} & \multirow[b]{2}{*}{$\begin{array}{c}\text { SLBW, } \\
\text { kg }\end{array}$} & \multicolumn{4}{|c|}{ \% of LBW } & \multicolumn{2}{|c|}{$\%$ of evisc.carcass } \\
\hline & & & $\begin{array}{l}\text { Evisc. } \\
\text { carcass }\end{array}$ & $\begin{array}{c}\text { Total } \\
\text { giblets }\end{array}$ & $\begin{array}{l}\text { Total } \\
\text { ed. } \\
\text { parts }\end{array}$ & $\begin{array}{c}\text { Abd. } \\
\text { fat }\end{array}$ & $\begin{array}{l}\text { Breast } \\
\text { yield }\end{array}$ & $\begin{array}{l}\text { Thigh } \\
\text { yield }\end{array}$ \\
\hline \multicolumn{9}{|c|}{ Sex effect $(S)$} \\
\hline \multirow{2}{*}{\multicolumn{2}{|c|}{$\begin{array}{c}\text { Male (M.) } \\
\text { Female }(\mathrm{F} .)\end{array}$}} & $3436.0^{\mathrm{a}}$ & 72.81 & 4.49 & 77.30 & $0.98^{\mathrm{b}}$ & $47.69^{b}$ & $31.82^{\mathrm{b}}$ \\
\hline & & $2133.3^{b}$ & 72.60 & 4.54 & 77.13 & $1.18^{\mathrm{a}}$ & $50.56^{\mathrm{a}}$ & $33.10^{\mathrm{a}}$ \\
\hline \multicolumn{2}{|c|}{ Pooled SEM } & 32.1 & 0.45 & 0.05 & 0.45 & 0.06 & 0.33 & 0.40 \\
\hline \multicolumn{2}{|c|}{ Significance } & $* *$ & NS & $\mathrm{NS}$ & $\mathrm{NS}$ & $*$ & $* *$ & $*$ \\
\hline \multicolumn{9}{|c|}{ L-carnitine effect (LC, mg/kg diet) } \\
\hline \multicolumn{2}{|c|}{0.0} & 2770.8 & $69.51^{b}$ & $4.47^{\mathrm{bc}}$ & $73.98^{b}$ & $1.86^{\mathrm{a}}$ & $47.96^{\mathrm{b}}$ & $30.13^{c}$ \\
\hline \multicolumn{2}{|c|}{150} & 2800.0 & $72.61^{\mathrm{a}}$ & $4.96^{\mathrm{a}}$ & $77.57^{\mathrm{a}}$ & $0.93^{b}$ & $49.05^{a b}$ & $33.17^{\mathrm{ab}}$ \\
\hline \multicolumn{2}{|c|}{300} & 2791.7 & $73.79^{a}$ & $4.52^{\mathrm{b}}$ & $78.31^{\mathrm{a}}$ & $0.77^{\mathrm{b}}$ & $49.17^{a b}$ & $31.62^{\mathrm{bc}}$ \\
\hline \multicolumn{2}{|c|}{450} & 2791.7 & $73.81^{\mathrm{a}}$ & $4.26^{c}$ & $78.08^{a}$ & $1.06^{\mathrm{b}}$ & $50.00^{\mathrm{a}}$ & $32.67^{\mathrm{ab}}$ \\
\hline \multicolumn{2}{|c|}{600} & 2783.3 & $73.13^{\mathrm{a}}$ & $4.24^{c}$ & $77.37^{\mathrm{a}}$ & $0.86^{\mathrm{b}}$ & $49.14^{\mathrm{ab}}$ & $34.56^{\mathrm{a}}$ \\
\hline \multicolumn{2}{|c|}{750} & 2770.8 & $73.37^{\mathrm{a}}$ & $4.63^{b}$ & $78.01^{\mathrm{a}}$ & $1.02^{\mathrm{b}}$ & $49.41^{\mathrm{ab}}$ & $32.61^{\mathrm{ab}}$ \\
\hline \multicolumn{2}{|c|}{ Pooled SEM } & 55.5 & 0.78 & 0.08 & 0.79 & 0.11 & 0.57 & 0.70 \\
\hline \multicolumn{2}{|c|}{ Significance } & NS & $* *$ & ** & $* *$ & $* *$ & $*$ & $* *$ \\
\hline \multicolumn{9}{|c|}{ Interaction } \\
\hline \multirow[t]{2}{*}{ Sex } & LC & & & & & & & \\
\hline & 0.0 & 3350.0 & 69.48 & $4.27^{\mathrm{c}}$ & 73.74 & 2.05 & 46.49 & 29.90 \\
\hline \multirow{5}{*}{$\sum^{\frac{0}{\sigma}}$} & 150 & 3458.3 & 71.76 & $5.03^{\mathrm{a}}$ & 76.79 & 0.73 & 48.17 & 31.64 \\
\hline & 300 & 3433.3 & 74.05 & $4.82^{\mathrm{a}}$ & 78.87 & 0.64 & 48.04 & 32.25 \\
\hline & 450 & 3450.0 & 74.13 & $4.33^{\mathrm{bc}}$ & 78.47 & 0.99 & 47.92 & 32.95 \\
\hline & 600 & 3450.0 & 73.33 & $4.15^{\mathrm{c}}$ & 77.49 & 0.61 & 47.62 & 32.97 \\
\hline & 750 & 3475.0 & 74.11 & $4.33^{\mathrm{bc}}$ & 78.45 & 0.87 & 47.90 & 31.22 \\
\hline \multirow{6}{*}{ 窇 } & 0.0 & 2191.7 & 69.54 & $4.68^{\mathrm{ab}}$ & 74.22 & 1.66 & 49.44 & 30.36 \\
\hline & 150 & 2141.7 & 73.46 & $4.89^{\mathrm{a}}$ & 78.35 & 1.12 & 49.94 & 34.70 \\
\hline & 300 & 2150.0 & 73.53 & $4.22^{\mathrm{c}}$ & 77.75 & 0.90 & 50.29 & 30.99 \\
\hline & 450 & 2133.3 & 73.49 & $4.19^{c}$ & 77.69 & 1.13 & 52.08 & 32.39 \\
\hline & 600 & 2116.7 & 72.93 & $4.32^{\mathrm{bc}}$ & 77.24 & 1.12 & 50.66 & 36.15 \\
\hline & 750 & 2066.7 & 72.63 & $4.93^{\mathrm{a}}$ & 77.56 & 1.16 & 50.92 & 34.00 \\
\hline \multicolumn{2}{|c|}{ Pooled SEM } & 78.5 & 1.10 & 0.12 & 1.11 & 0.16 & 0.80 & 0.99 \\
\hline \multicolumn{2}{|c|}{ Significance } & NS & $\mathrm{NS}$ & ** & $\mathrm{NS}$ & NS & NS & NS \\
\hline
\end{tabular}

a,b,c :means in the same column within each item bearing different superscripts are significantly different $(\mathrm{P} \leq 0.05)$,

$\mathrm{SEM}=$ stander error mean; NS $=$ non-significant; $*=\mathrm{P} \leq 0.05 ; * *=\mathrm{P} \leq 0.01$ 
Table (4): Effect of sex, dietary L-carnitine addition and their interaction on chemical analysis of breast and thigh muscles for Sudani ducklings at 16 wks of age.

\begin{tabular}{|c|c|c|c|c|c|c|c|c|c|}
\hline \multirow{2}{*}{\multicolumn{2}{|c|}{$\begin{array}{l}\text { Main } \\
\text { effects }\end{array}$}} & \multicolumn{4}{|c|}{ Breast muscles contents, $\%$} & \multicolumn{4}{|c|}{ Thigh muscles contents, $\%$} \\
\hline & & DM & $\mathbf{C P}$ & EE & Ash & DM & $\mathbf{C P}$ & EE & Ash \\
\hline \multicolumn{10}{|c|}{ Sex effect $(S)$} \\
\hline \multirow{2}{*}{\multicolumn{2}{|c|}{$\begin{array}{c}\text { Male } \\
\text { Female }\end{array}$}} & 28.81 & 60.83 & $32.76^{\mathrm{b}}$ & 4.20 & 27.91 & $61.84^{\mathrm{a}}$ & $33.14^{\mathrm{b}}$ & 3.72 \\
\hline & & 29.10 & 61.07 & $33.50^{\mathrm{a}}$ & 4.02 & 27.84 & $60.38^{\mathrm{b}}$ & $34.06^{\mathrm{a}}$ & 4.10 \\
\hline \multicolumn{2}{|c|}{ Pooled SEM } & 0.19 & 0.27 & 0.18 & 0.14 & 0.29 & 0.46 & 0.33 & 0.21 \\
\hline \multicolumn{2}{|c|}{ Significance } & $\mathrm{NS}$ & $\mathrm{NS}$ & $*$ & $\mathrm{NS}$ & $\mathrm{NS}$ & $*$ & $*$ & $\mathrm{NS}$ \\
\hline \multicolumn{10}{|c|}{ L-carnitine effect (LC, mg/kg diet) } \\
\hline \multicolumn{2}{|c|}{0.0} & $27.85^{\mathrm{c}}$ & $55.81^{\mathrm{c}}$ & $38.67^{\mathbf{a}}$ & 4.01 & $26.80^{\mathbf{b}}$ & $55.49^{c}$ & $38.75^{\mathrm{a}}$ & 3.82 \\
\hline \multicolumn{2}{|c|}{150} & $28.63^{\text {bc }}$ & $60.95^{b}$ & $33.24^{\mathbf{b}}$ & 3.86 & $27.75^{\text {ab }}$ & $58.96^{\mathbf{b}}$ & $35.59^{\mathbf{b}}$ & 3.87 \\
\hline \multicolumn{2}{|c|}{300} & $28.81^{\text {bc }}$ & $63.31^{\mathrm{a}}$ & $31.53^{\mathrm{c}}$ & 4.02 & $29.05^{\mathrm{a}}$ & $63.46^{\mathbf{a}}$ & $31.59^{\mathrm{c}}$ & 3.97 \\
\hline \multicolumn{2}{|c|}{450} & $29.30^{\mathbf{a b}}$ & $62.49^{\mathrm{a}}$ & $31.32^{\mathrm{c}}$ & 3.94 & $27.73^{\mathrm{ab}}$ & $62.98^{\mathrm{a}}$ & $32.09^{c}$ & 3.51 \\
\hline \multicolumn{2}{|c|}{600} & $29.96^{\mathrm{a}}$ & $59.93^{\mathbf{b}}$ & $32.99^{\mathbf{b}}$ & 4.48 & $27.76^{\mathbf{a b}}$ & $62.93^{\mathrm{a}}$ & $31.76^{\mathrm{c}}$ & 3.78 \\
\hline \multicolumn{2}{|c|}{750} & $29.19^{\mathbf{a b}}$ & $63.20^{\mathbf{a}}$ & $31.03^{c}$ & 4.34 & $28.17^{\mathbf{a b}}$ & $62.84^{\mathrm{a}}$ & $31.83^{c}$ & 4.48 \\
\hline \multicolumn{2}{|c|}{ Pooled SEM } & 0.33 & 0.47 & 0.30 & 0.25 & 0.50 & 0.80 & 0.56 & 0.36 \\
\hline \multicolumn{2}{|c|}{ Significance } & $* *$ & $* *$ & $* *$ & $\mathrm{NS}$ & $*$ & $* *$ & $* *$ & $\mathrm{NS}$ \\
\hline \multicolumn{10}{|c|}{ Interaction } \\
\hline Sex & LC & & & & & & & & \\
\hline \multirow{6}{*}{$\sum^{\frac{0}{\sigma}}$} & 0.0 & $28.31^{\mathrm{bc}}$ & $55.25^{\mathrm{c}}$ & $38.70^{\mathrm{a}}$ & 4.13 & $27.09^{\mathbf{b c}}$ & 55.95 & 38.65 & 3.30 \\
\hline & 150 & $28.28^{\mathrm{bc}}$ & $62.41^{\mathrm{a}}$ & $31.93^{b}$ & 3.78 & $28.74^{\mathrm{a}}$ & 59.32 & 35.33 & 4.26 \\
\hline & 300 & $29.09^{\mathrm{ab}}$ & $63.32^{\mathrm{a}}$ & $31.53^{b}$ & 3.75 & $28.18^{a b}$ & 63.93 & 31.44 & 3.61 \\
\hline & 450 & $28.60^{\mathrm{bc}}$ & $60.67^{a b}$ & $31.40^{\mathrm{b}}$ & 4.00 & $27.80^{\mathrm{b}}$ & 63.75 & 31.62 & 3.45 \\
\hline & 600 & $29.02^{\mathrm{ab}}$ & $60.76^{\mathbf{a b}}$ & $31.38^{\mathbf{b}}$ & 4.94 & $26.78^{c}$ & 64.17 & 30.71 & 3.57 \\
\hline & 750 & $29.57^{\mathrm{a}}$ & $62.60^{a}$ & $31.63^{\mathbf{b}}$ & 4.63 & $28.88^{\mathrm{a}}$ & 63.90 & 31.09 & 4.11 \\
\hline \multirow{6}{*}{ 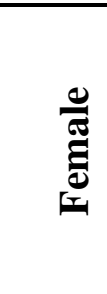 } & 0.0 & $27.38^{c}$ & $56.37^{\mathrm{c}}$ & $38.65^{\mathrm{a}}$ & 3.88 & $26.50^{c}$ & 55.04 & 38.84 & 4.33 \\
\hline & 150 & $28.99^{\mathrm{ab}}$ & $59.42^{\mathbf{b c}}$ & $34.56^{\mathrm{ab}}$ & 3.95 & $26.76^{c}$ & 58.60 & 35.85 & 3.49 \\
\hline & 300 & $28.52^{\mathrm{bc}}$ & $63.30^{\mathrm{a}}$ & $31.54^{\mathbf{b}}$ & 4.30 & $29.91^{\mathrm{a}}$ & 62.98 & 31.75 & 4.34 \\
\hline & 450 & $29.99^{\mathrm{a}}$ & $64.32^{\mathrm{a}}$ & $31.23^{b}$ & 3.89 & $27.65^{b}$ & 62.21 & 32.56 & 3.58 \\
\hline & 600 & $30.90^{\mathrm{a}}$ & $59.11^{\text {bc }}$ & $34.60^{\mathrm{ab}}$ & 4.03 & $28.75^{\mathbf{a b}}$ & 61.69 & 32.81 & 3.99 \\
\hline & 750 & $28.81^{\mathrm{bc}}$ & $63.81^{\mathrm{a}}$ & $30.42^{\mathbf{b}}$ & 4.06 & $27.45^{\text {bc }}$ & 61.77 & 32.57 & 4.84 \\
\hline \multicolumn{2}{|c|}{ Pooled SEM } & 0.46 & 0.66 & 0.43 & 0.35 & 0.71 & 1.13 & 0.80 & 0.51 \\
\hline \multicolumn{2}{|c|}{ Significance } & $* *$ & ** & ** & NS & $*$ & NS & NS & $\mathrm{NS}$ \\
\hline
\end{tabular}

$\mathrm{DM}=$ dry matter; $\mathrm{CP}=$ crude protein; $\mathrm{EE}=$ ether extract

$a, b, c$ :means in the same column within each item bearing different superscripts are significantly different $(\mathrm{P} \leq 0.05), \mathrm{SEM}=$ stander error mean; $\mathrm{NS}=$ non-significant; $*=$ $\mathrm{P} \leq 0.05 ; * *=\mathrm{P} \leq 0.01$ 
Ducklings sex, L-carnitine, growth performance, carcass and meat quality.

Table (5): Effect of sex, dietary L-carnitine addition and their interaction on blood hematology parameters of Sudani ducklings at 14 wks of age.

\begin{tabular}{|c|c|c|c|c|c|c|c|c|}
\hline \multirow{2}{*}{\multicolumn{2}{|c|}{$\begin{array}{l}\text { Parameters } \\
\text { effects }\end{array}$}} & \multicolumn{4}{|c|}{ Serum constituents } & \multicolumn{3}{|c|}{ Hematological parameters } \\
\hline & & $\begin{array}{l}\text { Trigly., } \\
\text { mg/dl }\end{array}$ & $\begin{array}{c}\text { T. } \\
\text { cholest., } \\
\text { mg/dl }\end{array}$ & $\begin{array}{c}\text { AST, } \\
\text { U/dl }\end{array}$ & $\begin{array}{l}\text { ALT, } \\
\text { U/dl }\end{array}$ & $\begin{array}{c}\text { Heteroph } \\
\%\end{array}$ & $\begin{array}{c}\text { Lymph, } \\
\%\end{array}$ & $\mathbf{H} / \mathbf{L}$ \\
\hline \multicolumn{9}{|c|}{ Sex effect $(S)$} \\
\hline \multicolumn{2}{|c|}{ Male } & 83.12 & $123.23^{b}$ & 55.14 & 15.40 & 23.78 & 76.22 & 0.32 \\
\hline \multicolumn{2}{|c|}{ Female } & 83.09 & $127.31^{\mathrm{a}}$ & 54.81 & 15.31 & 23.56 & 76.33 & 0.31 \\
\hline \multicolumn{2}{|c|}{ Pooled SEM } & 0.52 & 1.06 & 0.96 & 0.30 & 0.33 & 0.33 & 0.01 \\
\hline \multicolumn{2}{|c|}{ Significance } & NS & $* *$ & NS & NS & $\mathrm{NS}$ & NS & NS \\
\hline \multicolumn{9}{|c|}{ L-carnitine effect (LC, mg/kg diet) } \\
\hline \multicolumn{2}{|c|}{0.0} & $97.64^{\mathrm{a}}$ & $138.73^{\mathrm{a}}$ & 53.55 & 15.82 & $29.83^{\mathrm{a}}$ & $70.17^{d}$ & $0.43^{\mathrm{a}}$ \\
\hline \multicolumn{2}{|r|}{150} & $78.20^{\mathrm{d}}$ & $123.65^{b}$ & 54.83 & 14.87 & $26.33^{\mathrm{b}}$ & $73.67^{\mathrm{c}}$ & $0.36^{\mathrm{b}}$ \\
\hline \multicolumn{2}{|r|}{300} & $81.26^{b c}$ & $122.06^{\mathrm{b}}$ & 56.75 & 15.57 & $22.33^{\mathrm{cd}}$ & $77.33^{b}$ & $0.29^{c}$ \\
\hline \multicolumn{2}{|r|}{450} & $78.51^{\mathrm{cd}}$ & $121.63^{b}$ & 54.63 & 15.34 & $20.67^{\mathrm{de}}$ & $79.33^{\mathrm{a}}$ & $0.26^{\mathrm{d}}$ \\
\hline \multicolumn{2}{|r|}{600} & $79.49^{\mathrm{cd}}$ & $122.23^{b}$ & 55.31 & 15.50 & $22.50^{c}$ & $77.50^{b}$ & $0.29^{c}$ \\
\hline \multicolumn{2}{|r|}{750} & $83.54^{\mathrm{b}}$ & $123.32^{b}$ & 54.80 & 15.04 & $20.33^{\mathrm{e}}$ & $79.67^{\mathrm{a}}$ & $0.26^{d}$ \\
\hline \multicolumn{2}{|c|}{ Pooled SEM } & 0.90 & 1.84 & 1.66 & 0.51 & 0.58 & 0.58 & 0.01 \\
\hline \multicolumn{2}{|c|}{ Significance } & $* *$ & $* *$ & $\mathrm{NS}$ & $\mathrm{NS}$ & $* *$ & $* *$ & $* *$ \\
\hline \multicolumn{9}{|c|}{ Interaction } \\
\hline Sex & LC & & & & & & & \\
\hline \multirow{6}{*}{$\frac{\stackrel{0}{\sigma}}{\sum}$} & 0.0 & 98.56 & 134.24 & 54.56 & 15.88 & 30.33 & 69.67 & 0.44 \\
\hline & 150 & 75.79 & 120.06 & 53.14 & 14.71 & 26.67 & 73.33 & 0.36 \\
\hline & 300 & 82.60 & 120.43 & 55.19 & 15.92 & 22.00 & 78.00 & 0.28 \\
\hline & 450 & 78.81 & 122.22 & 54.86 & 15.12 & 20.67 & 79.33 & 0.26 \\
\hline & 600 & 79.46 & 120.38 & 57.97 & 15.77 & 23.33 & 76.67 & 0.31 \\
\hline & 750 & 83.55 & 122.03 & 55.16 & 15.00 & 19.67 & 80.33 & 0.25 \\
\hline \multirow{6}{*}{ } & 0.0 & 96.73 & 143.21 & 52.55 & 15.77 & 29.33 & 70.67 & 0.42 \\
\hline & 150 & 80.61 & 127.24 & 56.52 & 15.04 & 26.00 & 74.00 & 0.35 \\
\hline & 300 & 79.93 & 123.70 & 58.31 & 15.22 & 22.67 & 76.67 & 0.30 \\
\hline & 450 & 78.21 & 121.05 & 54.41 & 15.55 & 20.67 & 79.33 & 0.26 \\
\hline & 600 & 79.52 & 124.08 & 52.65 & 15.23 & 21.67 & 78.33 & 0.28 \\
\hline & 750 & 83.53 & 124.62 & 54.45 & 15.09 & 21.00 & 79.00 & 0.27 \\
\hline \multicolumn{2}{|c|}{ Pooled SEM } & 1.28 & 2.61 & 2.35 & 0.73 & 0.82 & 0.82 & 0.01 \\
\hline \multicolumn{2}{|c|}{ Significance } & $*$ & $\mathrm{NS}$ & $\mathrm{NS}$ & $\mathrm{NS}$ & $\mathrm{NS}$ & $\mathrm{NS}$ & $\mathrm{NS}$ \\
\hline
\end{tabular}

a,b... d :means in the same column within each item bearing different superscripts are significantly different $(\mathrm{P} \leq 0.05), \mathrm{SEM}=$ stander error mean;

NS $=$ non-significant; $*=\mathrm{P} \leq 0.05 ; * *=\mathrm{P} \leq 0.01$ 
Table (6): Effect of sex, dietary L-carnitine addition and their interaction on economic efficiency (EEF) of Sudani ducklings during 4-16 wks of age.

\begin{tabular}{|c|c|c|c|c|c|c|c|c|c|}
\hline \multirow{2}{*}{\multicolumn{2}{|c|}{$\begin{array}{l}\text { Parameters } \\
\text { Main } \\
\text { effects }\end{array}$}} & \multicolumn{2}{|c|}{$\begin{array}{l}\text { Feed cons., } \\
\text { kg/duckling }\end{array}$} & \multirow{2}{*}{$\begin{array}{l}\text { Feed } \\
\text { cost } \\
(\mathbf{L E})\end{array}$} & \multirow{2}{*}{$\begin{array}{c}\text { LC } \\
\text { cost } \\
(\mathbf{L E})\end{array}$} & \multirow{2}{*}{$\begin{array}{l}\text { Total } \\
\text { cost } \\
(\mathrm{LE})\end{array}$} & \multirow{2}{*}{$\begin{array}{c}\text { Total } \\
\text { return } \\
(\text { LE) }\end{array}$} & \multirow{2}{*}{$\begin{array}{c}\text { Net } \\
\text { return } \\
(\text { LE) }\end{array}$} & \multirow{2}{*}{ EEF } \\
\hline & & $\begin{array}{l}4-8 \\
\text { wk }\end{array}$ & $\begin{array}{c}\text { 8-16 } \\
\text { wk }\end{array}$ & & & & & & \\
\hline \multicolumn{10}{|c|}{ Sex effect $(S)$} \\
\hline \multirow{2}{*}{\multicolumn{2}{|c|}{$\begin{array}{c}\text { Male } \\
\text { Female }\end{array}$}} & $3.76^{\mathrm{a}}$ & $7.45^{\mathrm{a}}$ & $51.67^{\mathrm{a}}$ & $1.11^{\mathrm{a}}$ & $70.78^{a}$ & $103.91^{\mathrm{a}}$ & $33.12^{\mathrm{a}}$ & $0.468^{\mathrm{a}}$ \\
\hline & & $2.39^{b}$ & $4.75^{b}$ & $32.94^{\mathbf{b}}$ & $0.71^{\mathbf{a}}$ & $48.64^{b}$ & $62.39^{b}$ & $13.75^{\mathbf{b}}$ & $0.283^{b}$ \\
\hline \multicolumn{2}{|c|}{ Pooled SEM } & 0.03 & 0.08 & 0.37 & 0.01 & 0.37 & 0.55 & 0.65 & 0.01 \\
\hline \multicolumn{2}{|c|}{ Significance } & $*$ & $*$ & $* *$ & $* *$ & $* *$ & $* *$ & $* *$ & $* *$ \\
\hline \multicolumn{10}{|c|}{ L-carnitine effect (LC, mg/kg diet) } \\
\hline \multicolumn{2}{|c|}{0.0} & $3.02^{\mathrm{b}}$ & 6.09 & 42.01 & $0.00^{\mathrm{f}}$ & $58.51^{\mathbf{b}}$ & $75.54^{\mathrm{c}}$ & $17.03^{\mathrm{c}}$ & $0.274^{\mathrm{c}}$ \\
\hline \multicolumn{2}{|c|}{150} & $3.18^{\mathrm{a}}$ & 6.08 & 42.72 & $0.37^{\mathrm{e}}$ & $59.59^{b}$ & $86.44^{\mathrm{a}}$ & $26.85^{a}$ & $0.434^{\mathrm{a}}$ \\
\hline \multicolumn{2}{|c|}{300} & $3.19^{\mathrm{a}}$ & 5.90 & 41.99 & $0.72^{d}$ & $59.21^{b}$ & $84.74^{\mathrm{ab}}$ & $25.52^{\mathbf{a b}}$ & $0.420^{\mathrm{a}}$ \\
\hline \multicolumn{2}{|c|}{450} & $3.02^{b}$ & 6.08 & 41.93 & $1.08^{\mathrm{c}}$ & $59.51^{\mathbf{b}}$ & $82.64^{\mathbf{b}}$ & $23.13^{b}$ & $0.375^{\mathbf{a b}}$ \\
\hline \multicolumn{2}{|c|}{600} & $3.00^{\mathrm{b}}$ & 6.08 & 41.83 & $1.43^{b}$ & $59.76^{b}$ & $85.44^{\mathrm{ab}}$ & $25.67^{a b}$ & $0.412^{\mathrm{a}}$ \\
\hline \multicolumn{2}{|c|}{750} & $3.05^{b}$ & 6.36 & 43.33 & $1.86^{\mathrm{a}}$ & $61.69^{a}$ & $84.10^{\mathbf{a b}}$ & $22.41^{\mathrm{b}}$ & $0.340^{\mathbf{b}}$ \\
\hline \multicolumn{2}{|c|}{ Pooled SEM } & 0.05 & 0.13 & 0.63 & 0.01 & 0.64 & 0.96 & 1.12 & 0.02 \\
\hline \multicolumn{2}{|c|}{ Significance } & $*$ & $\mathrm{NS}$ & $\mathrm{NS}$ & $* *$ & $*$ & $* *$ & $* *$ & $* *$ \\
\hline \multicolumn{10}{|c|}{ Interaction } \\
\hline \multirow[t]{2}{*}{ Sex } & $\mathbf{L C}$ & & & & & & & & \\
\hline & 0.0 & 3.76 & 7.41 & 51.51 & $0.00^{d}$ & 69.51 & $95.00^{\mathbf{b}}$ & 25.49 & 0.367 \\
\hline \multirow{5}{*}{$\stackrel{\frac{0}{\sigma}}{\sum}$} & 150 & 3.86 & 7.36 & 51.79 & $0.44^{\mathrm{c}}$ & 70.23 & $107.45^{a}$ & 37.22 & 0.530 \\
\hline & 300 & 3.90 & 7.18 & 51.19 & 0.87 bc & 70.06 & $104.20^{\mathbf{a}}$ & 34.14 & 0.489 \\
\hline & 450 & 3.67 & 7.43 & 51.15 & $1.31^{\mathbf{b}}$ & 70.46 & $102.45^{a}$ & 31.99 & 0.454 \\
\hline & 600 & 3.62 & 7.47 & 51.05 & $1.75^{\mathrm{ab}}$ & 70.80 & $106.75^{a}$ & 35.95 & 0.508 \\
\hline & 750 & 3.74 & 7.85 & 53.33 & $2.29^{\mathrm{a}}$ & 73.62 & $107.58^{\mathbf{a}}$ & 33.96 & 0.461 \\
\hline \multirow{6}{*}{ 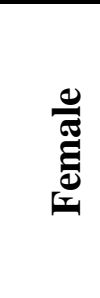 } & 0.0 & 2.29 & 4.78 & 32.51 & $0.00^{\mathrm{d}}$ & 47.51 & $56.08^{d}$ & 8.57 & 0.181 \\
\hline & 150 & 2.50 & 4.80 & 33.65 & $0.29^{\mathrm{c}}$ & 48.94 & $65.43^{c}$ & 16.49 & 0.337 \\
\hline & 300 & 2.48 & 4.63 & 32.80 & $0.56^{\mathrm{c}}$ & 48.36 & $65.27^{\mathrm{c}}$ & 16.91 & 0.351 \\
\hline & 450 & 2.36 & 4.74 & 32.71 & $0.84^{\text {bc }}$ & 48.55 & $62.83^{c}$ & 14.27 & 0.296 \\
\hline & 600 & 2.37 & 4.70 & 32.61 & $1.12^{\mathbf{b}}$ & 48.72 & $64.13^{c}$ & 15.40 & 0.316 \\
\hline & 750 & 2.37 & 4.87 & 33.34 & $1.43^{\mathbf{a b}}$ & 49.76 & $60.62^{\mathrm{cd}}$ & 10.85 & 0.218 \\
\hline \multicolumn{2}{|c|}{ Pooled SEM } & 0.07 & 0.19 & 0.90 & 0.21 & 0.92 & 1.35 & 1.59 & 0.03 \\
\hline \multicolumn{2}{|c|}{ Significance } & NS & $\mathrm{NS}$ & NS & $*$ & $\mathrm{NS}$ & $*$ & $\mathrm{NS}$ & $\mathrm{NS}$ \\
\hline
\end{tabular}

Total cost $=$ feed cost $+\mathrm{LC}$ cost + duckling price at 4 wks of age ( female, $15 \mathrm{LE}$ and male , 18 $\mathrm{LE})$; total return $=$ body weight $\mathrm{x} \mathrm{kg}$ wt. price; net return= total return- total cost; $\mathrm{EEF}=$ economic efficacy $=$ net return $/$ total cost.

$\mathrm{LE}=$ Egyptian pound; $\mathrm{SEM}=$ stander error mean .

$\mathrm{a}, \mathrm{b} \ldots \mathrm{e}$ :means in the same column within each item bearing different superscripts are significantly different $(\mathrm{P} \leq 0.05) ; \mathrm{NS}=$ non-significant; $*=\mathrm{P} \leq 0.05 ; * *=\mathrm{P} \leq 0.01$ 
Ducklings sex, L-carnitine, growth performance, carcass and meat quality.

\section{REFERENCES}

Abdel-Fattah, S. A.; El-Daly, E. F. and Ali, N. G. M., 2014. Growth performance, immune response, serum metabolites and digestive enzyme activities of Japanese quail fed supplemental L-Carnitine. Global Vet., 12: $277-286$.

AOAC, 1995. Official Methods of Analysis. $16^{\text {th }}$ ed. Assoc. of Anal. Hem., Washington, DC.

Arslan, C.; Itil, M. C. and Saatc, M., 2003. Effects of L-carnitine administration on growth performance, carcass traits, blood serum parameters and abdominal fatty acid composition of ducks. Arch. Anim. Nutr., 57: 381 388.

Awad, A. L.; Fahim, H. N. and Beshara, M. M., 2016. Effect of dietary L-carnitine supplementation on productive performance and carcass quality of local duck breeds in summer season. Egypt. Poult. Sci., 36: 11-27.

Awad, A. L.; Ibrahim, A. F.; Fahim, H. N. and Beshara, M. M., 2014. Effect of dietary betaine supplementation on growth performance and carcass traits of Domyati ducklings under summer conditions. Egypt. Poult. Sci., 34:1019-1038.

Bayram İ.; Akıncı, Z. and Uysal, H., 1999. Effects of dietary supplementation of L-carnitine and vitamin $\mathrm{C}$ on growth and laying performance in Japanese quail (Coturnix coturnix Japonica), (in Turkish). J. Vet. Fac. Yüzüncü Y1l Uni., 10: 32-37.

Bernacki, Z.; Kokoszyński, D. and Mallek, T., 2008. Evaluation of selected meat traits in seven-week-old duck broilers. J. Anim. Sci., 26: 165174.

Castillo, C.C.; Pinto, A. A.; Souza, G. L.; Beraquet, N. J.; Aguiar, A. P.; Cipolli, K. M. V. A. B.; Mendes, C. M. I. and Ortega, E. M., 2007.Effects of feed withdrawal periods on carcass yield and breast meat quality of chickens reared using an alternative system. J. Appl. Poult. Res. 16:613622.

Daskiran, M. and Teeter, R.G., 2001. Effects of dietary L-carnitine (carniking @) supplementation on overall performance and carcass characteristics of seven-week-old broiler chickens. Anim. Sci. Res. Rep.http://www.ansi.okstate.edu/resea $\mathrm{rch} / 2001 \mathrm{rr} / 35 / 35 . \mathrm{htm}$

Deng, K.; Wong, C.W. and Nolan, J.V. , 2006. Long-term effects of early-life dietary L-carnitine on lymphoid organs and immune responses in Leghorn- type chickens. J. Anim. Phys. Anim. Nutr., 90: 81-86.

Duncan, D.B., 1955.Multiple range and multiple F tests. Biometrics, 11:1-42.

Fathi, E. and Farahzadi, R., 2014. Application of l-carnitine as nutritional supplement in veterinary medicine. Rom. J. Biochem., 51: 31-41.

Feed Composition Tables for Animals and Poultry Feedstuffs Used in Egypt, 2001. Technical Bulletin No., 1, Central Lab. For Food and Feeds (CLFF) Ministry of Agric. Res. Cent. Egypt.

Gross, W.B. and Siegel, P.B., 1986. Effects of initial and second periods of fasting on heterophil / lymphocyte ratios and body weight. Av. Dis., 30:345 346 
Hossininezhad, M.M.; Irani, M. and Seidavi, A., 2011. Dietary effects of L-carnitine supplement on performance and blood parameters of broiler chickens. J. of Food, Agric. Envi., 9: 475-481.

Jameel, Y.J., 2014.Effect of the content of fish oil, 1- carnitine $(50 \mathrm{mg} / \mathrm{kg})$ and their combination in diet on immune response and some blood parameters of broilers.Int. J. Sci. Nat. vol., 5: 501504

Kalaiselvi, T. and Panneerselvam, C., 1998. Effect of L-carnitine on the status of lipid peroxidation and antioxidants in aging rats. J. Nutr. Biochem., 9: 575-581.

Lara, L.J. and Rostagno, M.H., 2013. Impact of heat stress on poultry production. Anim. J., 3:356-369.

Maritza, F.D.; Julio, A.U.; Flor, L. and Frank, H.R., 2006. L-carnitineinduced modulation of plasma fatty acids metabolism in hyperlipidemia rabbits. Rev. Electron Biomed / Electron. J. Biomed., 1: 33-41.

Michalczuk, M.; Lukasiewicz, M.; Niemiec, J.; Wnuk, A. and Sosnowska, N. M., 2012. Effect of Lcarnitine on performance and dressing percentage of broiler chickens. Anim. Sci., 51: 89-99.

Murali, P.; George, S. K.; Ally, K. and Dipu, M. T., 2015. Effect of Lcarnitine supplementation on growth performance, nutrient utilization, and nitrogen balance of broilers fed with animal fat. Vet. World. 8: 482-486.

North, O.M., 1981. Commercial chicken production manual. $2^{\text {nd }}$ Ed., AVI Publishing company, Inc., Westpor, Connecticut.
Oladele, O.A.; Adeboye, F.; Richard, S. and Zainob, H., 2011. Growth response, carcass yield and serum biochemistry of broiler chicken feds with supplemental L-carnitne in feed or drinking water. J. Poult. Sci., 48: 223-228.

Olayemi, F.; Oyewale, J.; Rahman, S. and Omolewa, O., 2003.Comparative assessment of the white blood cell values, plasma volume and blood volume in the young and adult Nigerian duck (Anas platyrhynchos). Vet. Arhiv. 73: $270-276$.

Parsaeimehr, K.; Afrouziyeh, M. and Hoseinzadeh, S., 2014. The effects of L-carnitine and different levels of animal fat on performance, carcass characteristics, some blood parameters and immune response in broiler chicks. IranJ. Appl. Anim. Sci., 4: 561-566.

Rezaei. M.; Attar, A.; A. Ghodratnama and Kermanshahi, H., 2007.Study the effects of different levels of fat and Lcarnitine on performance, carcass characteristics and serum composition of broiler chicks. Pak. J. Biol. Sci., 15; 10:1970-1976.

Sari, M.; K. Önk; S. Işik; M. Tilki and T. Tufan,2013.Effects of housing system, slaughter age, and sex on slaughter and carcass traits of native Turkish ducks. Turk. J. Vet. Anim. Sci., 37: 694-700.

Sarica, S.; Corduk, M. and Kilinc, K., 2005. The effect of dietary L-carnitine supplementation on growth performance, carcass traits and composition of edible meat in Japanese quail (Coturnix coturnix japonica). J. Appl. Poult. Res., 14: 709-715. 
Ducklings sex, L-carnitine, growth performance, carcass and meat quality.

SAS Institute, 2004. SAS User's Guide: Statistics. Edition 9.1. SAS Institute Inc. Cary, NC.

Schuurs, A.H. and Verheul, H.A., 1990. Effects of gender and sex steroids on the immune response. J. Steroid Biochem., 35:157-172.

Shuenn, D.Y.; Fu, G.I. and Chyng, H.I., 2012. Effects of dietary Lcarnitine, plant proteins and lipid levels on growth performance, body composition, blood traits and muscular carnitine status in juvenile silver perch (Bidyanus bidyanus). Aquaculture 342-343.

Simaraks, S.; Chinrasri, O. and Aengwanich, W., 2004. Haematological, electrolyte and serum biochemical values of the Thai indigenous chickens (Gallus domesticus) in northeastern Thailand. Songklanakarin J. Sci. Tec., 26:425-430.

Taklimi, S.M.; Ghazvinian, K. and Kasgari, M. R. A., 2015. Effect of Lcarnitine on performance and carcass quality of broiler chickens. Acad. J. Sci. Res., 3: 50-54.

Tufan, T.; Arslan, C.; Durna, Ö. ; Önk, K.; Sarl, M. and Erman, H., 2015. Effects of chito-oligosaccharides and L-carnitine supplementation in diets for Japanese quails on performance, carcass traits and some blood parameters. Arq. Bras. Med. Vet. Zootec., 67:283-289.

Wawro, K.; Wilkiewicz-Wawro, E.; Kleczek, K. and Brzozowski, W., 2004. Slaughter value and meat quality of Muscovy ducks, Pekin ducks and their crossbreeds, and evaluation of the heterosis effect. Arch. Tierz., Dummerstorf, 47: 287299.

Xu, Z.R.; Wang, M.Q.; Mao, H.X.; Zhan, X.A. and Hu, C.H., 2003. Effects of L-carnitine on growth performance, carcass composition and metabolism of lipids in male broilers. Poult. Sci., 82: 408-413.

Younis, M. E. M., 2015. Influence of dietary 1-carnitine on productive performance, internal organs and carcass characters of two duck breeds reared for foiegras production. Alex. J. Vet. Sci., 44: 159-168.

Zhang Y.; Ma, Q.; Bai, X.; Zhao, L.; Wang, Q.; Ji, C.; Liu, L. and Yin, H., 2010. Effects of dietary acetyl-Lcarnitine on meat quality and lipid metabolism in Arbor Acres broilers. Asian-Australasian J. Anim. Sci., 12:1639-1644. 


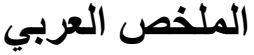

\section{تأثير الجنس وإضافة إلكارنيتين على أداء النمو وجودة الأبيحة لكتاكيت البط السودانى

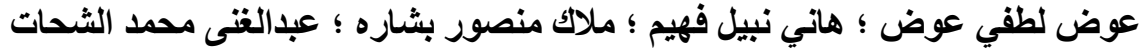

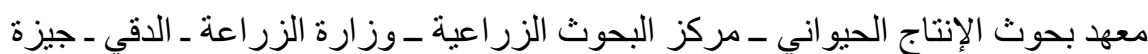

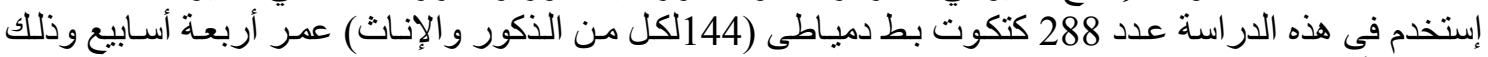

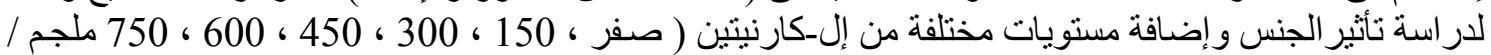

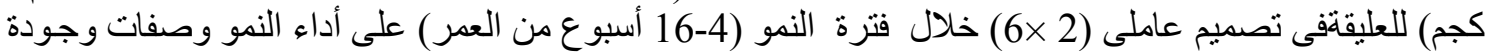

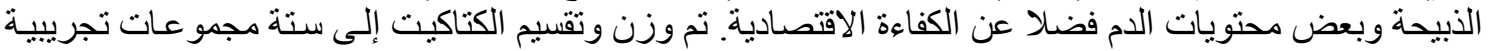

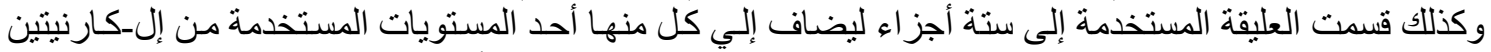

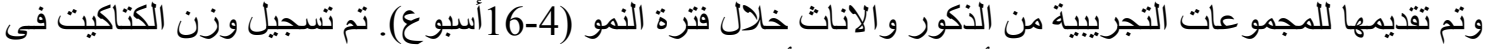

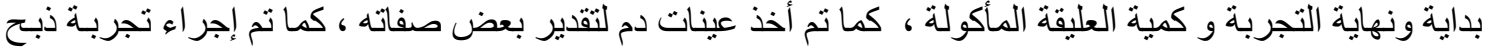

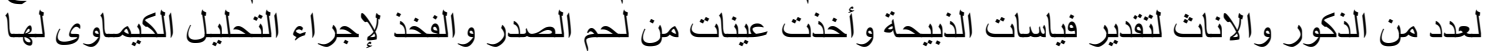
، كما تم حساب الكفاءة الاقتصادية للتغذية خلال الفترة الكلية للتجربة (4-16 أسبو ع) .

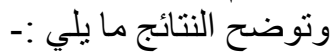

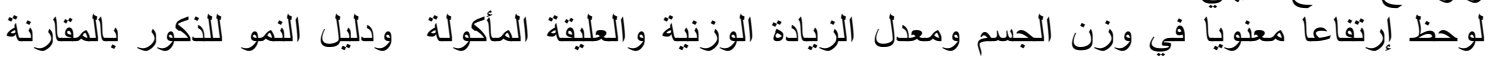

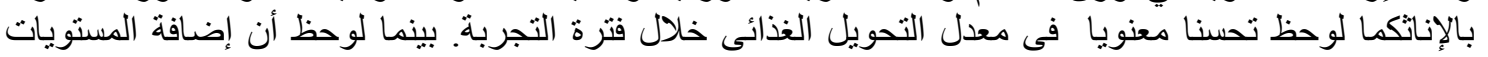

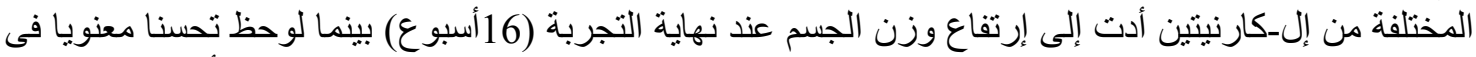

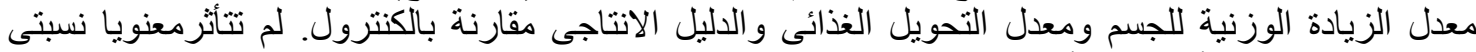

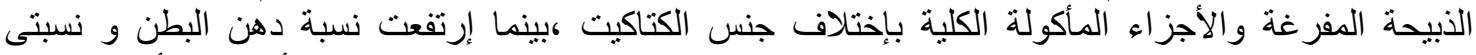

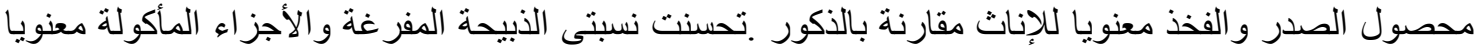

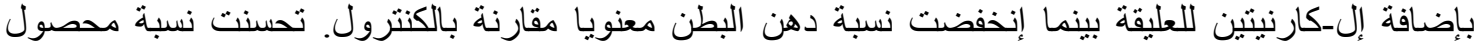

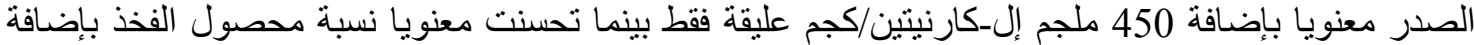

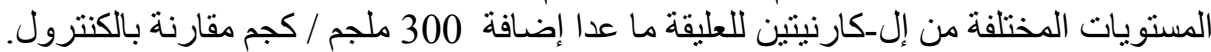

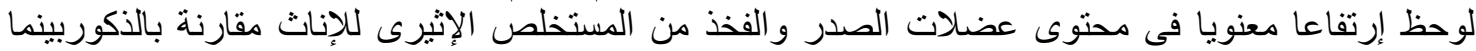

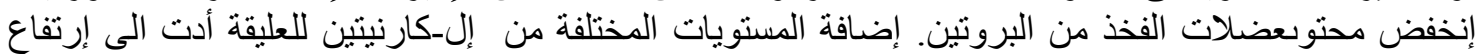

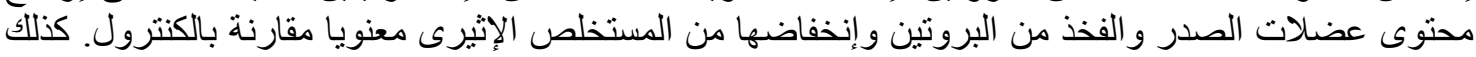

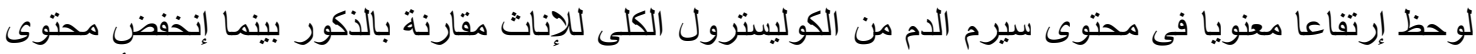

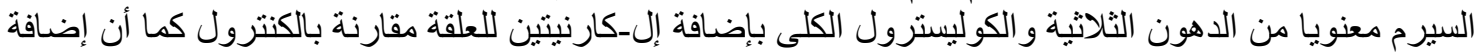

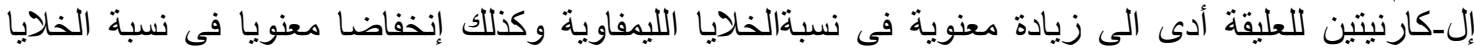

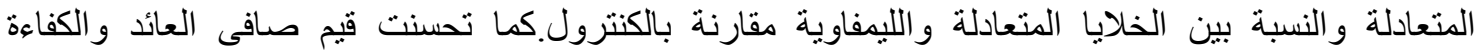

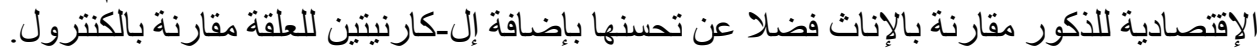

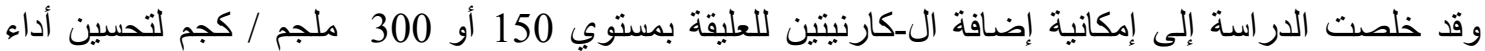

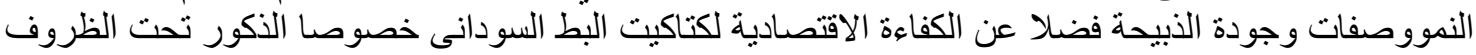
المصرية. 